\title{
Paradigma-verschuivingen in de visie op zorg voor mensen met een verstandelijke handicap
}

Citation for published version (APA):

van Gennep, A. T. G. (1997). Paradigma-verschuivingen in de visie op zorg voor mensen met een verstandelijke handicap. Maastricht University. https://doi.org/10.26481/spe.19970228ag

Document status and date:

Published: 28/02/1997

DOI:

10.26481/spe.19970228ag

Document Version:

Publisher's PDF, also known as Version of record

\section{Please check the document version of this publication:}

- A submitted manuscript is the version of the article upon submission and before peer-review. There can be important differences between the submitted version and the official published version of record. People interested in the research are advised to contact the author for the final version of the publication, or visit the DOI to the publisher's website.

- The final author version and the galley proof are versions of the publication after peer review.

- The final published version features the final layout of the paper including the volume, issue and page numbers.

Link to publication

\footnotetext{
General rights rights.

- You may freely distribute the URL identifying the publication in the public portal. please follow below link for the End User Agreement:

www.umlib.nl/taverne-license

Take down policy

If you believe that this document breaches copyright please contact us at:

repository@maastrichtuniversity.nl

providing details and we will investigate your claim.
}

Copyright and moral rights for the publications made accessible in the public portal are retained by the authors and/or other copyright owners and it is a condition of accessing publications that users recognise and abide by the legal requirements associated with these

- Users may download and print one copy of any publication from the public portal for the purpose of private study or research.

- You may not further distribute the material or use it for any profit-making activity or commercial gain

If the publication is distributed under the terms of Article $25 \mathrm{fa}$ of the Dutch Copyright Act, indicated by the "Taverne" license above, 


\section{2}




\section{PARADIGMA-VERSCHUIVING IN DE VISIE OP ZORG VOOR MENSEN MET EEN VERSTANDELIJKE HANDICAP}

\section{REDE}

uitgesproken bij de aanvaarding van het ambt

van bijzonder hoogleraar Zorg voor verstandelijk

gehandicapten (Gouverneur Kremers Leerstoel),

aan de Universiteit Maastricht

op vrijdag 28 februari 1997

door

Dr A.Th.G. van Gennep 
PPN's $15649549 x$

$$
\begin{aligned}
& \text { lis rentiblisilizok } \\
& \text { Ur. oinot thatsiricht }
\end{aligned}
$$


Mijnheer de Rector Magnificus,

Zeergeleerde Kremers,

Dames en Heren,

\section{Inleiding}

Iedere samenleving heeft bepaalde politieke, sociale en pedagogische grondhoudingen, die ook de omgang met personen met een verstandelijke handicap vastleggen. Deze grondhoudingen zijn ingebed in de culturele traditie en in het dominerende politieke en economische systeem. Ze leiden de principes van het handelen, de vormen van institutionalisering en de productie van wetenschappelijke theorieën (Bleidick, 1985).

Dat deze theorieën verband houden met een bepaalde historischmaatschappelijke context, wil niet zeggen dat ze tot deze context gereduceerd kunnen worden. Het wil wel zeggen dat theorieën niet ontstaan in een historisch-maatschappelijk vacuum.

Deze historisch-maatschappelijke inbedding van wetenschappelijke theorieën is een gevolg van het feit, dat de gemeenschap van onderzoekers niet los staat van de omringende maatschappij en van de tijd waarin zij leeft. Binnen het kader van een bepaalde historisch-maatschappelijke context wordt door de 
gemeenschap van onderzoekers een bepaalde code van regels afgesproken, die het mogelijk maakt een bepaalde afstand te creëren ten opzichte van de historisch-maatschappelijke context en hierdoor rationeel met elkaar te discussiëren en vast te stellen, welke theorieën of hypothesen op basis van de afgesproken regels als wetenschappelijk worden geaccepteerd (Kolakowski, 1981 , p. 456).

De theorie, die door de onderzoekers wordt aangehangen, wordt paradigma genoemd. Het begrip paradigma werd door Thomas Kuhn in de wetenschapstheorie geïntroduceerd. Met dit begrip duidde hij een wetenschappelijke prestatie aan, die gedurende enige tijd modelproblemen en modeloplossingen verschaft aan een gemeenschap van onderzoekers (1970, p. VIII).

De meeste wetenschappen kennen verschillende paradigma's. De verschillen ontstaan, doordat wetenschappelijk onderzoek altijd versmolten is met persoonlijk en historisch toeval, waardoor een paradigma altijd iets willekeurigs heeft.

De kern van het paradigma wordt tegen theoretische en historische kritiek geïmmuniseerd. Gegevens die niet 'passen' in dit paradigma en ook niet 'passend'te maken zijn, worden genegeerd of weggedrukt. Maar dat valt op de duur niet vol te houden. Na verloop van tijd blijken namelijk steeds meer gegevens niet te 'passen' en ondermijnen daardoor het dominerende 
paradigma. De kruik gaat zo lang te water tot zij breekt. Dit laatste gebeurt pas ma enige tijd van wetenschappelijke conflicten en controversen. Als er een nieuw paradigma ontstaat, waarin de gegevens wél 'passen', wordt het oude paradigma door steeds meer aanhangers losgelaten ten gunste van het nieuwe. Dit noemen wij een paradigma-verschuiving.

Het wetenschappelijk onderzoek naar verstandelijke handicap is ontstaan rond 1800, in het Frankrijk van de Verlichting. In die historisch-maatschappelijke context werd een hoge waarde toegekend aan het verstand, de ratio. Het dominerende paradigma was dat van Descartes. Deze ging uit van het bestaan van aangeboren ideeën. Hiertegenover ontstond toen een nieuw paradigma, het sensualisme van Condillac. Deze ging er van uit, dat alle kennis begint bij de ervaring. Via de zintuigen komen de ervaren prikkels in het verstand, de centrale zin. Door het vasthouden van het gemeenschappelijke van vele ervaringen, via associatie, ontstaan algemene ideeën. Deze zijn dus niet aangeboren, maar verworven door opvoeding.

In opdracht van de minister van binnenlandse zaken werd de doven-arts Itard in 1801 belast met de opvoeding van de Wilde van Aveyron, een jongen die in de bossen was gevonden. Door deze opvoeding moest Itard de controverse tussen de aanhangers van de twee paradigma's beslechten. Als hij de jongen kon opvoeden, dan was daarmee aangetoond dat het sensualistisch paradigma 
juist was. De uitslag is bekend. Aanvankelijk verliep de opvoeding zeer succesvol. Deze aanvankelijke successen wezen in de richting van het gelijk van de sensualistische opvatting. Dit gaf de stoot tot wetenschappelijke onderzoeken in Europa en Noord-Amerika. Maar na enige tijd bleken de resultaten toch tegen te vallen. Het medisch model ontstond en na enige tijd het sociaal-darwinisme en in het voetspoor hiervan segregatie in grote instituten ver van de samenleving (Van Gennep, 1980,1981).

$\mathrm{Na}$ de Tweede Wereldoorlog ontstond geleidelijk een nieuw paradigma, namelijk het normalisatie-paradigma. Dit paradigma had een grote invloed op het beleid en de organisatie van de zorg voor mensen met een verstandelijke handicap.

\section{Normalisatie}

Het normalisatie-paradigma heeft volgens Kent Ericsson (wiens historisch overzicht ik hier kort weergeef, Ericsson, 1996, p.81 e.v.) zijn wortels in de Zweedse verzorgingsstaat, zoals die vanaf de jaren veertig gestalte kreeg. In 1943 werd een regeringscommissie geïnstalleerd, die tot taak kreeg voorstellen te doen met betrekking tot adequate zorg- en dienstverlening aan 
personen met een lichte handicap, opdat zij een goed bestaan zouden kunnen hebben. De commissie stelde voor om uit te gaan van het principe dat de licht gehandicapten, voor zo ver mogelijk, opgenomen zouden moeten worden in het gewone systeem van sociale dienstverlening. De commissie ging er van uit, dat 'normalisatie' van de woonomstandigheden, het onderwijs, de arbeid enz. positieve consequenties zou hebben voor de betrokken personen met een handicap. Dit 'normalisatie-principe' hield o.a. in, dat speciale instituten een uitzondering zouden moeten blijven. Dit was in Zweden het startpunt voor de ontwikkeling van voorzieningen voor personen met een lichte handicap in de samenleving in de jaren vijftig en daarna.

Ook in Denemarken ontstond in de jaren vijftig discussie over de rechten van personen met een handicap. Die discussie, waarin de jurist en beleidsambtenaar Bank-Mikkelsen een centrale rol speelde, resulteerde in een nieuwe wet op de gehandicaptenzorg, in 1959. De sleutel van deze nieuwe wet lag in een klein zinnetje, namelijk dat de verstandelijk gehandicapte een bestaan moet kunnen leiden dat 'zo dicht bij het normale ligt als maar mogelijk is'. De uitleg van dit zinnetje heeft er toe geleid, dat men in Denemarken het normalisatieprincipe is gaan hanteren voor alle personen met een verstandelijke handicap, dus niet alleen voor degenen met een lichte handicap. 
In 1967 werd in Zweden een nieuwe wet op de gehandicaptenzorg aangenomen. Een belangrijk aandeel in het totstandkomen van deze wet had de psycholoog en ombudsman van de oudervereniging Bengt Nirje. Hij formuleerde het normalisatieprincipe als volgt: "het toegankelijk maken voor personen met een verstandelijke handicap van patronen en omstandigheden van het dagelijkse leven, die zo dicht mogelijk bij die van de hoofdstroom van de samenleving liggen" (B. Nirje, 1969). Nirje werkte dit principe uit in acht punten: 1) een normaal dagritme; 2) een normaal weekritme; 3) een normaal jaarritme; 4) ervaringen van de normale fasen van de levenscyclus; 5) keuzen, wensen en vragen van de betrokkene worden gerespecteerd; 6) leven in een bisexuele wereld; 7) een normale economische levensstandaard; 8) de standaarden voor fysieke voorzieningen voor personen met een verstandelijke handicap moeten dezelfde zijn als die voor niet-gehandicapte burgers. Deze acht punten gelden volgens Nirje voor alle personen met een verstandelijke handicap, niet alleen voor personen met een lichte handicap. Het nieuwe paradigma was geboren. 


\section{Effecten van normalisatie}

Sinds 1969 wordt het normalisatie-principe gehanteerd als beleidsprincipe.

Wat zijn de resultaten hiervan?

Het belangrijkste resultaat was een grootscheepse de-institutionalisatie. Met name in West-Europa en Noord-Amerika, waar de meeste instituten waren, zijn de bewoners op grote schaal teruggeplaatst in de samenleving, tot tevredenheid van hun ouders en/of familieleden. Steeds meer instituten worden gesloten. Nederland vormt in dit opzicht een uitzondering: ongeveer de helft van alle personen met een verstandelijke handicap (IQ<55) woont in Nederland in een instituut en het aantal instituutsplaatsen neemt nog steeds enigszins toe.

Het leven in de samenleving heeft voor de betrokkenen tot gevolg, dat de kwaliteit van het bestaan verbetert. Dat wil zeggen: de betrokkenen hebben nu gewone leefpatronen; zij ontwikkelen zich als individuen; zij maken gebruik van de dienstverlening en faciliteiten die ook voor andere burgers van de samenleving beschikbaar zijn. Kortom, zij hebben een bestaan als de anderen en met de anderen in de samenleving.

Dit is het belangrijkste effect van het nieuwe wetenschappelijke paradigma. 


\section{Kritiek op normalisatie}

Niet iedereen was echter even gelukkig met het nieuwe paradigma. Vanaf het begin waren er punten van kritiek en in de loop van de tijd kwamen er nog meer bij.

De belangrijkste daarvan zal ik nu bespreken.

1. Een eerste punt van kritiek komt van een van de theoretici van normalisatie, namelijk de Zweed Kent Ericsson. Hij stelt, dat het normalisatieproces een tweedimensionale verandering betekent: een fysiekstructurele verandering en een verandering van perspectief.

- de fysiek-structurele verandering houdt in, dat personen met een verstandelijke handicap niet meer in een instituut worden geplaatst, maar dat zij in de gewone samenleving blijven wonen (thuis of elders) en dat ook hun dagbesteding en recreatie in de samenleving plaatsvinden.

- de verandering van perspectief, van visie op personen met een verstandelijke handicap houdt in, dat men deze personen niet meer beschouwt als personen met een beperkte handelingscompetentie, maar als volwaardige burgers van de samenleving. Zij zijn net als de andere burgers in de samenleving geboren en hebben daarom dezelfde rechten en plichten; maar vanwege hun beperkingen hebben zij ondersteuning nodig om volwaardig te kunnen participeren in de samenleving. 
De kritiek van Ericsson is nu, dat het normalisatieproces beperkt is gebleven

tot de fysiek-structurele dimensie, waar op een mechanische en

bureaucratische wijze vorm aan is gegeven. Maar normalisatie bedoelde meer, namelijk uitdrukking geven aan aan de sociaal-politieke idee, dat personen met een verstandelijke handicap een positie in de samenleving moeten krijgen als volwaardig burger.

2. Een tweede punt van kritiek is dat in kleinschalige woonvoorzieningen in de samenleving nog steeds een inrichtingscultuur heerst. Sinson (1990) en Gunzburg (1992) spreken in dit verband van micro-institutionalisatie. Dit heeft te maken met het feit, dat normalisatie werd gereduceerd tot kleinschaligheid. Maar normalisatie houdt meer in dan kleinschaligheid, namelijk een verandering :

- van leven apart van de samenleving naar leven in de samenleving,

- van grotere naar kleinere woongemeenschappen,

- van grotere naar kleinere leefgroepen,

- van groepsmatig naar geïndividualiseerd wonen,

- van meer gestructureerd naar minder gestructureerd wonen.

Alleen wanneer deze aspecten in hun samenhang gerealiseerd worden, is er sprake van normalisatie. Die normalisatie wordt in de woonsituatie zichtbaar in de wooncultuur. Deze wooncultuur biedt de bewoners een woonklimaat, dat zij nodig heben voor een actief persoonlijk bestaan. Kenmerken zijn o.a. 
zelfstandigheid, keuzemogelijkheid, verantwoordelijkheid. Het gaat er dus om, dat de begeleid(st)ers zelfstandigheid uitlokken, keuzemogelijkheden bieden en verantwoordelijkheden delegeren. De bewoners moeten invloed kunnen uitoefenen op hetgeen er in de woning gebeurt. Zij moeten het leven in 'hun' woning bepalen en ook de verantwoordelijkheid nemen voor de genomen besluiten. Zij moeten de vrijheid krijgen om veel dingen uit te proberen en daarbij ook beperkte risico's te lopen, bij voorbeeld met betrekking tot koken, kleren kopen, geld uitgeven, vriendschppen enz. De begeleiders moeten het leven en het ritme van het samenleven ondersteunen. Ook moeten zij de deelname aan het leven in de samenleving en de opbouw van sociale netwerken ondersteunen en stimuleren. Dit laatste noemt men sociale integratie. Uit diverse eigen onderzoeken is mij gebleken, dat dit laatstgenoemde het zwakste punt is van genormaliseerde woonvoorzieningen in de samenleving (Van Gennep, 1989, 1994). Functionele integratie valt nog mee, maar met sociale integratie is het slecht gesteld. In feite is er in de meeste Gezinsvervangende Tehuizen geen sprake van een wooncultuur, maar van een inrichtingscultuur. Kenmerken van de inrichtingscultuur zijn o.a.:

- afgeslotenheid ten opzichte van de omgeving,

- starheid van routines zonder rekening te houden met de mensen waar het om gaat,

- afzondering, waarbij de bewoners niet worden opgenomen in sociale 
netwerken,

- centralisatie, waarbij de bewoners de keuzemogelijkheden, de verantwoordelijkheden en de beslissingen worden afgenomen, - specialisatie, die de bewoner steeds enger en partiëler laat worden, ten koste van de 'hele' mens en alles ondergeschikt maakt aan het speciale, ten koste van het gewone.

De kleinschalige woonvoorzieningen in de samenleving hebben daarom volgens Bercovici (1981) het karakter van een 'subcultuur', vergeleken met de omgevende cultuur. Het Gezinsvervangend Tehuis produceert een beperkt perspectief voor de bewoners en dit resulteert bij de begeleid(st)ers in het onderschatten van de competentie van de bewoners. Dit leidt tot angst voor risico en tot een constant sturen en controleren van de bewoners. De kleinschalige woonvoorzieningen in de samenleving hebben daarom veelal het karakter van mini-instituten.

Taylor (1992) legt een belangrijke oorzaak hiervan bij de regelgeving van met name de overheid. Die regelgeving was oorspronkelijk gericht op instituten, om de kwaliteit van de zorg te garanderen. Maar als de regels buiten deze institutionele context gebruikt worden, verliezen zij hun rationale. Regelgeving vooronderstelt de onpersoonlijke, hiërarchische en bureaucratische structuur van instituten. Naarmate ze verder van deze structuur af staan, worden de regels irrationeler en contraproductiever. Dit 
levert de volgende paradox op. Om aan de regels te beantwoorden moet een woonsituatie onpersoonlijk, hiërarchisch en bureaucratisch worden en dit maakte de instituten juist minder humaan. Waar men in Gezinsvervangende Tehuizen probeert te komen tot meer bewonergerichte woonsituaties, daar drijft de regelgeving de woonsituatie in de richting van de instituutscultuur. Je kunt het volgens hem vergelijken met het onderwerpen van de maaltijden die thuis worden bereid, aan de regels die gelden voor fast food restaurants. Dat is de beste manier om die thuis bereide maaltijden te bederven. Als de groepsleiding in kleinschalige woonvoorzieningen zich houdt aan de regels, dan lijdt haar humaniteit hier onder en dit heeft weer een negatief effect op de manier van omgaan met bewoners met een verstandelijke handicap. Hierdoor worden die kleinschalige woonvoorzieningen in de samenleving mini-instituten.

3. Een derde bezwaar tegen normalisatie is het risico van 'ńormalizing to incompetence'(Kebbon, congres IASSID, Helsinki, 1996). Dat wil zeggen, dat normalisatie op zo'n manier kan worden uitgelegd, dat men geen aandacht besteedt aan de ontwikkeling van de competentie van personen met een verstandelijke handicap. Bij voorbeeld de manier waarop Ericsson spreekt over een verschuiving van perspectief, namelijk van 'competence' perspectief naar 'citizen' perspectief, kan aanleiding geven tot dit misverstand. Ericsson ziet dit risico wel. Hij stelt dan ook nadrukkelijk, dat het gaat om personen 
met beperkingen en dat daarom het verbeteren van de competentie een belangrijk doel blijft. De vraag is alleen, hoe dit moet gebeuren en hoe de visies van het betrokken individu moeten worden gerespecteerd (I996, p.90). Het gaat er hem om (en dat is het verschil tussen het 'citizen' perspectief en het 'competence' perspectief), dat de betrokken persoon met de verstandelijke handicap invloed heeft over wanneer, waar en hoe de ondersteuning wordt aangeboden.

Gunzburg heeft reeds in een vroeg stadium zijn reserves in dit opzicht tot uitdrukking gebracht. Reeds in 1974 stelde hij: normalisatie lijkt zowel een principe te zijn, dat ten grondslag ligt aan management praktijken alsook een einddoel dat moet worden nagestreefd, namelijk het opnemen van het individu in de 'normale' samenleving. Als een gids voor het vermijden van de gevaren van de 'abnormale situatie' kan het niet verbeterd worden. Maar het zal nog moeten blijken dat het ook een even nuttige gids is voor het bepalen van de meest effectieve praktijken en benaderingen bij het tegemoetkomen aan de behoeften van de verstandelijk gehandicapte" (1974, p. 652). Ook Felce (1996, p. 117-118) en Mansell (1996, p. 55-58) leggen thans de nadruk op training van het personeel in genormaliseerde woonvoorzieningen, op de manier waarop zij ondersteuning geven en het gebruik dat zij hierbij maken van geïndividualiseerde programma's. Ook in Nederland kennen wij het probleem van 'ńormalizing to 
incompetence'. In een longitudinaal onderzoek vergeleek ik de ontwikkeling van de competentie van de bewoners van traditionele Gezinsvervangende Tehuizen met die van bewoners van Gezinsvervangende Tehuizen waarin een emancipatorische benadering was ingevoerd. In de traditionele Gezinsvervangende Tehuizen bleken de bewoners over drie jaren niet statistisch significant te zijn vooruitgegaan wat betreft hun competentie; in de meer emancipatorisch gerichte Gezinsvervangende Tehuizen bleken de bewoners wél statistisch significant te zijn vooruitgegaan in dit opzicht (Van Gennep, 1994).

Kortom: normalisatie alleen is niet voldoende, ook een speciale wijze van ondersteuning is nodig om 'normalizing to incompetence' te voorkomen. Maar dit wordt niet altijd gezien of wordt vaak ontkend.

4. Een vierde punt van kritiek heeft betrekking op het zogenaamde wooncontinuum. Dit begrip ontstond toen men begon te denken over 'community care' als alternatief voor 'institutional care'. De instituten werden beschouwd als de meest restrictieve omgevingen, terwijl het zelfstandig wonen met enige begeleiding werd beschouwd als de minst restrictieve omgeving. Tussen deze twee uitersten ontstonden nog enkele woonvormen. Samen konden die woonvormen op een continuum geplaatst worden, van meer naar minder restrictief, hetgeen de facto samenviel met : van minder naar meer genormaliseerd. Hoe meer genormaliseerd, hoe minder restrictief. 
Ook in Nederland is zo'n systeem ontstaan: instituut - sociowoning gezinsvervangend tehuis - dependance. Op basis van diverse onderzoeken heb ik empirisch kunnen vaststellen, dat hier sprake is van een continuum van minder naar meer genormaliseerd wonen. De bewoners van deze typen woonvoorzieningen kunnen op een parallelcontinuum geplaatst worden, van lager naar hoger niveau van functioneren (Van Gennep, 1989, 1994). Bewoners worden, op basis van hun functioneren, in een voor hen minst restrictieve omgeving geplaatst. De kritiek op dit systeem is, dat dit continuum functioneert als een soort ladder. Iedere sport van de ladder stelt dan een bepaald type woonvoorziening voor. In zo'n woonvoorziening kan de bewoner dan de vaardigheden leren, die nodig zijn om een sport hoger op de ladder te komen. Met andere woorden, er wordt van uitgegaan, dat personen met een verstandelijke handicap eerst over bepaalde vaardigheden moeten beschikken, alvorens ze mogen doorstromen naar een volgende minder restrictieve omgeving. Ze moeten het mensenrecht op meer zeggenschap over hun eigen woonsituatie als het ware eerst 'verdienen'. Met name personen met een (zeer) ernstige verstandelijke handicap komen hier nooit aan toe en zijn dus veroordeeld om altijd te wonen in een zeer restrictieve woonsituatie (Allard, 1996, p.101). Men wil zo veel mogelijk risico vermijden. Bercovici (1981) wijst er bovendien op, dat het in de praktijk in feite vaak gaat om het produceren van 'normaal gedrag' en 'normale verschijning'. 
De kritiek hierop is van tweeërlei aard:

- enerzijds moeten wij uitgaan van de behoeften, wensen en keuzen van de betrokken persoon; dit mensenrecht mag niet worden beperkt. Vervolgens moeten wij deze persoon ondersteunen waar dit nodig is.

- anderzijds is het niet zo, dat wij vooraf moeten leren iets te doen om, nadat blijkt dat wij de vereiste vaardigheden beheersen, deze in praktijk mogen brengen. In een omvangrijk longitudinaal onderzoek (Lozano,1993) bleek, dat de vaardigheden van verstandelijk gehandicapte bewoners, die vooraf geen training kregen, verbeterden als effect van het zelfstandig wonen met ondersteuning. De reële ervaring is belangrijk. Wij moeten dus niet iemand pas zelfstandig laten wonen nadat hij bewezen heeft over de vaardigheden daartoe te beschikken. Nee, wij moeten iemand die de wens daartoe te kennen geeft, zelfstandig laten wonen en daarbij die steun geven, die nodig is. Het aanleren van specifieke vaardigheden moet gebeuren op basis van de concrete woonervaring.

Een zelfde kritiek als op het wonen is er ook op de dagbesteding. Ik zal daar hier niet verder op ingaan.

5. Een vijfde punt van kritiek kwam al in een vroeg stadium van een voorvechter van normalisatie, namelijk de Amerikaan van Duitse afkomst Wolfensberger. Hij poogde het normalisatie-principe in twee opzichten te verwetenschappelijken (Thimm,1985): 
- enerzijds moest het losgemaakt worden van de Scandinavische context;

- anderzijds moest het opgevat worden als een universeel principe voor omgang met sociaal deviante personen.

Hiertoe herformuleerde hij het normalisatie-principe als volgt: normalisatie is het gebruik van cultureel gewaardeerde middelen met de bedoeling persoonlijke gedragingen, ervaringen en kenmerken te ontwikkelen en/of in stand te houden, die in de samenleving gebruikelijk zijn of positief gewaardeerd worden (Wolfensberger, 1972). Maar ook deze herformulering bevredigde hem niet. Daarom kwam hij in 1983 met een nieuwe herformulering, gekoppeld aan een nieuw begrip: sociale rol valorisatie. Deze sociale rol valorisatie is gericht op het tot stand brengen, verbeteren of verdedigen van de sociale rol(len) van personen of groepen die bedreigd worden met sociale devaluatie, door middel van het verbeteren van hun sociale beeld en van hun persoonlijke competentie. Kortom, er staan twee strategieën voorop om sociale devaluatie ven personen met een verstandelijke handicap uit hun sociaal gedevalueerde rol te halen of te voorkómen dat zij hierin terecht komen: 1) reduceren of voorkómen van anderszijn (de uiterlijke kenmerken dus) die een persoon devalueren in de ogen van iemand die hem waarneemt; 2) veranderen van de maatschappelijke percepties en waarden met betrekking tot een gedevalueerde persoon of groep zo dat een gegeven kenmerk of persoon niet langer wordt gezien als gedevalueerd. 
Een voorbeeld van het reduceren van het anderszijn, van het uiterlijk, is plastische chirurgie bij kinderen met Down's syndroom. Het gaat hier om het inkorten van de tong, het opereren van neus en/of oogleden. Bij andere syndromen gaat het om het vergroten van de kin of de jukbeenderen. Het is overigens de vraag, nog afgezien van de ethische aspecten, of zo'n operatie het gewenste effect heeft. Het uiterlijk verandert wel, maar het gedrag niet. Bovendien worden er verwachtingen gewekt die niet kunnen worden waargemaakt.

Deze uitwerking van Wolfensberger heeft aanleiding gegeven tot felle kritiek, ook van de zijde van de Scandinaviërs. De kritiek bestaat hierin, dat volgens Wolfensberger normalisatie er op gericht is om de persoon met een verstandelijke handicap te maken tot een persoon die kan 'doorgaan' voor 'normaal' in termen van uiterlijk en gedrag. Of, zoals Nirje het uitdrukte: Wolfensberger vat gelijkwaardigheid op als gelijkvormigheid (Helsinki, IASSID congres, 1996). Wolfensberger stapt hiermee, ook naar zijn eigen mening, minstens gedeeltelijk over van een empirisch gefundeerd theoretisch kader naar een boven-empirisch waardensysteem. Normalisatie wordt hiermee een ideologie. Volgens de Canadees Perrin (Helsinki, IASSID congres, 1996) verschoof in Wolfensbergers herinterpretaties de essentie van normalisatie, namelijk van nadruk op rechten en zelfbepaling naar conformiteit aan de waarden van anderen, van de samenleving. Een normatieve interpretatie. Deze 
interpretatie is onjuist: het gaat er bij normalisatie juist om, dat het normaal is om verschillend te zijn. Daarom moet niet de persoon met een verstandelijke handicap veranderen, maar zijn fysieke en sociale omgeving, ja de hele samenleving, om tegemoet te kunnen komen aan mensen met hun verschillen.

Samengevat komt de kritiek dus op het volgende neer. Er is slechts sprake van fysiek-structurele veranderingen, waardoor personen met een verstandelijke handicap niet meer in voorzieningen buiten maar in de samenleving wonen; die voorzieningen zijn geordend op een continuum naar het niveau van functioneren; maar ook in die voorzieningen heerst een instituutscultuur die o.a.leidt tot verwaarlozing van de ontwikkeling van competentie dan wel tot aanpassing in uiterlijk en gedrag aan de bestaande samenleving.

\section{Consequenties van de kritiek op normalisatie}

In essentie heeft de kritiek te maken met de onduidelijkheid van het concept. De Zweed Kent Ericsson geeft dit ook toe als hij schrijft: "Het normalisatieprincipe van 1946 geeft aan het burgerschapsperspectief een andere functie. De sociaal-politieke idee die normalisatie is, blijkt soms moeilijk te begrijpen 
en is aanleiding geworden tot een uitgebreid debat. Tijdens het proces van verandering is normalisatie vaak op een mechanische en bestuurlijke wijze toegepast. Het loutere bestaan al van de twee perspectieven (het competentieperspectief en het burgerschapsperspectief $A v G$ ) kan worden gezien als een uiting van het gebrek aan helderheid met betrekking tot de intenties en de inhoud van het normalisatieproces." (Ericsson, 1996, p.94). Maar ook de sociaal-politieke context van normalisatie verandert. De Zweed Kebbon stelt, dat de individualisering en economisering in de samenleving, met hun nadruk op onafhankeljkheid, de samenleving minder geschikt maken voor normalisatie (Helsinki, IASSID congres, 1996). De Noor Sandvin zegt het als volgt: "Het sociaal-politieke debat in Scandinavië ondergaat ideologische veranderingen. De traditioneel sterke steun voor de verschillende kenmerken van de Scandinavische verzorgingsstaten, zoals gelijkheid, centralisatie en universele sociale programma's, verdwijnt geleidelijk en wordt vervangen door waarden, die de nadruk leggen op individuele vrijheid en diversiteit, samenleving en netwerk, en decentralisatie van publieke dienstverlening. Er is een groeiende politieke steun voor private en vrijwillige regelingen als alternatieven voor de publieke sector. Deze ideologische veranderingen zijn niet louter Scandinavische verschijnselen. Decentralisatie en privatisering zijn algemene kenmerken geworden van de meeste Westerse landen sinds de jaren tachtig en Communitarisme en de wedergeboorte van 
de Idee van de Civil Society lijken de dominante ideologieën te worden in de jaren negentig." (1996, p.185) Het sociaal-politieke fundament onder normalisatie lijkt weg te zakken. De Canadees Perrin stelt dan ook:

normalisatie is dood, leve normalisatie. In een andere taal wordt thans

hetzelfde uitgedrukt (Helsinki, IASSID congres, 1996). In feite zegt hij

hiermee, dat de belangrijkste verworvenheden van normalisatie in een ander paradigma zijn opgenomen.

Met andere woorden: het normalisatie-tijdperk is ten einde. Het normalisatieparadigma wordt verdrongen door een nieuw paradigma, ingebed in de nieuwe sociaal-politieke structuur van de Westerse samenleving. Die nieuwe sociaal-politieke structuur heeft zijn oorsprong in de Verenigde Staten en van daaruit komt ook het nieuwe paradigma.

Het nieuwe paradigma

Het nieuwe paradigma heeft nog geen duidelijke naam. In de literatuur wordt het aangeduid met de term 'het nieuwe paradigma' (McFadden en Burke 1991, Bradley 1996). Het bestaat uit enkele onderdelen; die onderling min of meer samenhangen. Die onderdelen zijn de volgende. 
1. Het primaat van de samenleving.

Dit onderdeel is de belangrijkste erfenis van het normalisatie-paradigma.

Mensen met beperkingen behoren te leven in de samenleving als volwaardige burgers (Bradley 1996). Het burgersschapsperspectief houdt volgens Ericsson in, dat personen met een verstandelijke handicap op de eerste plaats burgers zijn, die net als de andere burgers geboren zijn in deze samenleving. Maar vanwege zijn beperkingen zal de burger met een verstandelijke handicap ondersteuning van anderen nodig hebben om te kunnen participeren in het maatschappelijk leven (1996, p.89).

Dit burgerschapsperspectief is niet beperkt tot de sector van de verstandelijk gehandicapten; ook in andere sectoren van de zorg vinden wij dit perspectief. Volgens Van Lieshout is de zorgvrager als burger iemand die tot op grote hoogte de condities bepaalt waaronder zorg verleend wordt. Dit zal volgens hem leiden tot een decategoralisering van de zorg. De klassieke zorgfuncties als verpleging en verzorging worden in toenemende mate gekoppeld aan functies als huisvesting, bescherming, vervoer, dagbesteding en opvang. Aangepast en op maat (1996, p.13).

2. Keuze en controle.

Ook de burgers met een verstandelijke handicap moeten zelf kunnen kiezen, waar en met wie zij willen wonen, werken en hun vrije tijd doorbrengen. Ook moeten zij zelf kunnen kiezen wie hen daarbij wanneer en hoe ondersteunt. 
Zij kunnen dan zelf vorm en inhoud geven aan hun eigen bestaan, uitgaande van hun algemeen-menselijke behoeften en hun speciale behoeften voortvloeiend uit de aard van hun beperkingen. Zo kunnen zij ook de controle over hun eigen leven krijgen en behouden.

Maar hier zit nu juist het probleem. De kern van de verstandelijke beperkingen bestaat juist hierin, dat personen met deze beperkingen problemen hebben met betrekking tot het plannen, sturen en beslissen hoe te handelen, de uitvoering van de handeling, het verwerven van nieuwe informatie, het tegemoet treden van nieuwe soorten taken en situaties, het aanpassen aan dan wel selecteren of omvormen van de omgeving waarin zij verkeren. Kortom, zij zijn hiertoe aangewezen op de hulp van anderen. Al te zeer werd tot voor kort het leven van personen met een verstandelijke handicap gecontroleerd door anderen. Dit resulteerde vaak in betutteling, met de beste bedoelingen overigens. In de literatuur wordt daarom het versterken van de controle over het eigen leven (empowerment) een belangrijk doel genoemd. Een belangrijk middel hiertoe is de persoonlijke toekomstplanning.

\section{Ondersteuning.}

In het nieuwe paradigma is het begrip zorg vervangen door het begrip

ondersteuning. Dit begrip kan worden omschreven als 'het toegang geven van de betrokken persoon tot voor hem belangrijke kennis, middelen en relaties 
die nodig zijn om in de samenleving te kunnen wonen, werken en recreëren. Ondersteuning heeft de volgende kenmerken.

a) Iemand hoeft niet 'klaar' te zijn, dat wil zeggen hoeft niet te voldoen aan bepaalde voorwaarden om te worden 'toegelaten' tot een bepaalde woon- of dagbestedingssituatie. Nee, het is juist de bedoeling om hem in de door hem gekozen situatie te plaatsen, daar ervaring te laten opdoen en te ondersteunen voor zo ver betrokkene (nog) niet over voldoende kennis, vaardigheden en relaties beschikt.

b) Ondersteuning wordt flexibel gegeven. Niet iedere persoon heeft even veel ondersteuning nodig; ook heeft niet iedere persoon op alle gebieden steun nodig; ten slotte kan er geleidelijk minder of meer steun nodig zijn in de loop van de tijd.

c) Ondersteunng wordt gegeven vanuit het sociale netwerk en het sociale vangnet. Het sociale netwerk bestaat uit de ouders, familieleden, vrienden, buren, mede-leerlingen op school, collega's op het werk, vrijwilligers. Het sociale vangnet bestaat uit de reguliere zorg- en dienstverlening (bij voorbeeld huisarts, thuiszorg, algemeen maatschappelijk werk, RIAGG, gemeentelijke sociale diensten enz.) en de speciale (categorale) zorg- en dienstverlening (bij voorbeeld het speciaal onderwijs, de sociale werkvoorziening en het professionele zorgsysteem). Het sociale vangnet moet pas in werking treden als het sociale netwerk te kort schiet. 
4. De kwaliteit van het bestaan.

De kwaliteit van de ondersteuning wordt afgemeten aan de mate, waarin die ondersteuning bijdraagt aan het mogelijk maken van een menswaardig bestaan, met andere woorden aan de kwaliteit van het bestaan. Maar de kwaliteit van de ondersteuning wordt ook afgemeten aan de mate, waarin die ondersteuning een goede kwaliteit van het bestaan in de weg staat (Van Houten en Van Lieshout 1994).

In de literatuur worden verschillende opvattingen over de kwaliteit van het bestaan aangetroffen. Bogdan en Taylor (1990) leggen de nadruk op de subjectieve ervaring van mensen. Het gaat volgens hen om de tevredenheid met het bestaan, zoals het individu die ervaart. Omdat dezelfde obectieve omstandigheden door verschillende mensen verschillend kunnen worden ervaren, kan de kwaliteit van het bestaan van verschillende mensen, die onder dezelfde omstandigheden leven, toch verschillend zijn. Die objectieve factoren brengen de subjectieve ervaringen weliswaar te weeg, maar dat doet niets af aan het gegeven, dat het gaat om de ervaring als zodanig. Volgens anderen zijn die objectieve factoren belangrijk, omdat zij het zijn, die de ervaring te weeg brengen. Hughes e.a. (1995) hebben op basis van uitgebreid literatuuronderzoek een consensuslijst van 15 objectieve dimensies samengesteld. Onder de top vijf vinden wij materieel, fysiek en psychisch welbevinden, persoonlijke keuze en tevredenheid, zelfbepaling, sociale 
relaties en werkgelegenheid.

Objectieve en subjectieve factoren lijken tegengesteld aan elkaar. Maar dit hoeft niet zo te zijn, als wij de objectieve factoren opvatten als opties, waarvoor het individu kan kiezen. De individuele keuze moet het leidende principe zijn voor elke actie die ondernomen wordt om de kwaliteit van het bestaan van het individu te verbeteren (Edgerton 1990). Op zo'n manier liggen objectieve en subjectieve factoren in het verlengde van elkaar.

Dit brengt ons tot de volgende omschrijving van de kwaliteit van het bestaan:

- het zelf vorm en inhoud geven aan het eigen bestaan volgens algemeenmenselijke en specifieke ( uit de aard van de beperkingen voortvoeiende) basisbehoeften,

- onder gewone leefomstandigheden en volgens gewone leefpatronen,

- zodanig dat de betrokkene tevreden is met het eigen bestaan.

Het nieuwe paradigma kent dus verschillende onderdelen die onderling min of meer samenhangen. 
De samenhang wordt in het volgende schema verduidelijkt.

\author{
volwaardig burgerschap
}

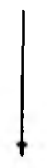

gewone ondersteuning $\longrightarrow$ keuze en controle $\longleftarrow$ professionele ondersteuning in sociaal netwerk

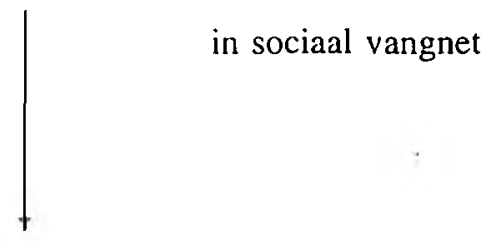

kwaliteit van het bestaan

Het nieuwe paradigma wordt soms aangeduid met de term ondersteuningsparadigma (support-paradigma, AAMR 1992). Wij moeten echter oppassen dat wij het totale paradigma niet versmallen door een bepaald onderdeel als pars pro toto centraal stellen. Wij vervallen dan in de zelfde fout als bij het normalisatie-paradigma, dat vaak werd versmald tot kleinschaligheid, met alle problemen van dien. 


\section{Theorie en praktijk}

De paradigma-verschuiving in de theorie heeft consequenties voor het beleid, de economie en de organisatie van de zorg. Aanzetten zijn reeds hier en daar zichtbaar. Maar de eerste problemen doen zich ook al voor. Ik zal er enkele noemen.

Het eerste probleem is de etikettenzwendel. Zorgaanbieders kunnen ten onrechte bestaande woonvoorzieningen 'ondersteund wonen' (supported living) gaan noemen en bestaande arbeidsprojecten 'ondersteund werken' (supported employment). Politici en beleidsmakers kunnen 'community care' (zorg in de samenleving) versmallen tot de ondersteuning door het sociaal netwerk ('mantelzorg'). In feite gaat het dan vaak om oude wijn in oude zakken met een nieuw etiket.

Het tweede probleem is de de-differentiatie of de-categorisatie van de zorg.

Hiermee wordt bedoeld, dat de diverse categorieën ondersteuning behoevenden in één brede, vage categorie worden samengebracht en ondersteuning ontvangen van breed maar algemeen opgeleide begeleiders. Dit kan leiden tot verlies aan betrokkenheid en expertise, omdat speciale behoeften onzichtbaar worden (Mansell en Ericsson 1996).

Een derde probleem is de (dreigende) tweedeling in de zorg voor mensen met een verstandelijke handicap. Van alle personen met een ernstiger vorm van 
verstandelijke handicap (grofweg alle personen met een $I Q<55$ ) verblijft ongeveer de helft in een instituut. De vernieuwingen in de afgelopen jaren waren vooral gericht op de andere helft, meest personen met een matige verstandelijke handicap. Vernieuwingen kunnen hier meestal plaatsvinden met gesloten beurzen en leiden soms tot inverdienen, al worden die inverdieneffecten zwaar overschat. Vanwege de veelomvattende (intensieve en specifieke) ondersteuning die een groot aantal bewoners van instituten nodig heeft, is daar nu al sprake van een forse achterstand en kan de vernieuwing voor deze groep slechts doorgang vinden met een forse financiële ondersteuning. Naar schatting minstens driekwart miljard en mogelijk zelfs een vol miljard gulden. Een fors bedrag. Maar het gaat goed met Nederland, zei de minister van financiën bij de begrotingspresentatie in 1996. Ik zou zeggen, laat de zwaksten in onze samenleving daar ook iets van merken. Wij leven immers in een democratische samenleving, dat is een samenleving van en voor allen. De grootste uitdaging voor onze samenleving is dan ook: hoe kunnen wij sociale solidariteit en onderlinge betrokkenheid opbouwen en in stand houden tussen mensen met verschillende behoeften talenten en aspiraties, opdat zij zich op een menswaardige manier kunnen ontplooien? (Mansell en Ericsson 1996, p.253). Séguin, de belangrijkste pionier van de zorg voor verstandeljk gehandicapten, zei het als volgt: God heeft onder ons uitgestrooid, even zeldzaam als het genie, de idioot... ten 
einde de rijke te binden aan de behoeftige, de getalenteerde aan de onbekwame, alle mensen aan elkaar. 


\section{Literatuur}

Allard, M.A.(1996). Supported Living Policies and Programmes. In: J.

Mansell and K. Ericsson (eds). Deinstitutionalization and Community Living.

Londen: Chapman \& Hall.

American Association on Mental Retardation (1992). Mental Retardation:

Definition. Classification and Systems of Support. Washington DC: AAMR

Bank-Mikkelsen, N.E.(1972). Iets over zwakzinnigen. In: J.Jepsen (ed.).

Behandeling van afwiikend gedrag. Den Haag: Bert Bakker.

Bercovici S.(1981). Qualitative Methods and Cultural Perspectives in the

Study of Deinstitutionalization. In: R.H. Bruininks, C.E. Meyers, B.B. Sigford and K.Ch.Lakin (eds). Deinstitutionalization and Community Adiustment of Mentally Retarded People. Washington DC: AAMR

Bleidick, U. (1985). Historische Theorien: Heilpädagogik, Sonderpädagogik, Pädagogik der Behinderten. In: U. Bleidick (Hrsg.). Theorie der

Behindertenpädagogik. Berlin: Marhold.

Bradley, V.(1996). Forword. In: J. Mansell and K. Ericsson (eds).

Deinstitutionalization and Community Living. London: Chapman \& Hall.

Edgerton, R.B. (1990). Quality of Life from a longitudinal research perspective. In: R.L. Schalock (ed.). Quality of Life: Perspectives and Issues. 
Washington DC: AAMR

Ericsson, K. (1996). Housing for the Person with Intellectual Handicap. In: J.

Mansell and K. Ericsson (eds). Deinstitutionalization and Community Living.

London: Chapman \& Hall.

Felce, D. (1996). Quality of Support for Ordinary Living. In: J. Mansell and

K. Ericsson (eds). Deinstitutionalization and Community Living. London:

Chapman \& Hall.

Gennep, A. van (1980). Naar een kritische orthopedagogiek.

Amsterdam/Meppel: Boom

Gennep, A. van (1981). Begaafdheid. Amsterdam/Meppel: Boom

Gennep, A. van (1989). De kwaliteit van het bestaan. Amsterdam/Meppel:

Boom

Gennep, A. van (1994). De zorg om het bestaan. Amsterdam/Meppel: Boom Gunzburg, H.C. (1974). Educational planning for the mentally handicapped.

In: A.M. Clarke and A.D.B. Clarke (eds). Mental Deficiency. The Changing

Outlook. Derde druk. London: Methuen.

Gunzburg, H.C. (1992). Aufgabenorientierte Persönlichkeitsentwicklung.

Heilpädagogische Forschung. Band XVIII, Heft 1: 1-10

Houten, D. van, en Lieshout, P. van (1994). De institutionalisering van de

zorg. In: H. Manschot, M. Verkerk (red.). Ethiek van de zorg.

Amsterdam/Meppel: Boom 
Hughes, C., Hwang, B., Jin-Ho, K., Eisenman, L.T. and Killian D.J. (1995).

Quality of Life in Applied Research: a Review and Analysis of Empirical

Measures. American Journal on Mental Retardation vol. 99, no 6: 623-641.

Kebbon, L. (1996). Nordic Contribution to Disability Policies. Helsinki:

IASSID congress

Kolakowski, L. (1981). Geschiedenis van het Marxisme 3.

Utrecht/Antwerpen: Het Spectrum.

Kuhn, Th.(1970). The Structure of Scientific Revolutions . 2de,vermeerderde druk. Chicago:The University of Chicago Press

Lieshout, P. van (1996). Verschuivende zorgconcepten en de antwoorden daarop. In: L.Boon (red.). Zorgvisies en management. Amstelveen: Stichting Sympoz.

Lozano, B. (1993). Independent Living: Relation among Training, Skills and Success. American Journal on Mental Retardation, 98, no 2: 249-262

Mansell, J. and Ericsson, K. (1996). Conclusion: integrating diverse experience. In: J. Mansell and K. Ericsson (eds). Deinstitutionalization and Communitv Living. London: Chapman \& Hall.

Mansell, J. (1996). Issues in Community Services in Britain. In: J. Mansell and $\mathrm{K}$. Ericsson (eds). Deinstitutionalization and Community Living. London: Chapman \& Hall.

May, D.C. (1988). Plastic Surgery for Children With Down Syndrome: 
Normalization or Extremism. Mental Retardation. vol. 26. no 1: 17-19

McFadden D.L. and Burke, E.P. (1991). Developmental Disabilities and the New Paradigm: Directions for the 1990s. Mental Retardation.vol. 29. no 2: III-VII.

Nirje, B. (1969). The Principle of Normalization and its Human Management Implications. In: R. Kugel and W. Wolfensberger (eds). Changing Patterns in Residential Services for the Mentally Retarded. Washington DC: The President's Committee on Mental Retardation.

Nirje, B. (1996). The Normalization Principle - Trends. Perspectives and Challenges. Helsinki: IASSID Congress.

Perrin, B. (1996). Bevond Normalization: Its Continuing Relevance for the 1990 s - and Beyond. Helsinki: IASSID congress.

Sandvin, J. (1996). The transition to Community Services in Norway. In: J. Mansell and K. Ericsson (eds). Deinstitutionalization and Communitv Living. London: Chapman \& Hall.

Sinson, J. (1990). Micro-institutionalization? Environmental and managerial influences in ten living units for people with mental handicap. The British Journal of Mental Subnormality. vol. XXXVI. part 2. no 71: 77-86.

Taylor, S.J. and Bogdan, R. (1990). Quality of Life and the Individual's perspective. In: R.L. Schalock (ed.). Quality of Life: Perspectives and Issues. Washington DC: AAMR 
Taylor, S.J. (1992). The Paradox of Regulations: A Commentary. Mental Retardation. vol. 30. no 3: $185-190$.

Thimm, W. (1985). Das Normalisierungsprinzid - Eine Einführung.

Marburg/Lahn: Bundesvereinigung Lebenshilfe für geistig Behinderte e.V.

Wolfensberger, W. (1972). The Principle of Normalization in Human

Services. Toronto: National Institute on Mental retardation.

Wolfensberger, W. (1983). Social Role Valorisation: A Proposed New Term for the Principle of Normalization. Mental Retardation. vol. 21. no 6:

234-239. 